Nedeljka Prole

Studijski program psihologije

Filozofski fakultet

Univerzitet u Banjoj Luci

Banja Luka, Republika Srpska, Bosna i Hercegovina

\title{
Svetlana Borojević
}

Laboratorija za eksperimentalnu psihologiju LEP-BL

Univerzitet u Banjoj Luci

Banja Luka, Republika Srpska, Bosna i Hercegovina

\section{DEPRESIVNOSTI VIZUELNO PAMĆENJE SPECIFIČNIH STIMULUSA (EMOTIKONA)}

\begin{abstract}
Apstrakt
Depresivnost predstavlja stanje smanjene psihofizičke aktivnosti koje je praćeno različitim promjenama u kognitivnom, emocionalnom i socijalnom funkcionisanju. Ranije studije su utvrdile da depresija dovodi do promjena u prepoznavanju emocija drugih, otežava usmjeravanje pažnje i značajno oštećuje vizuelnu memoriju. Osnovni cilj ovog istraživanja je ispitivanje povezanosti depresivnih simptoma sa zapamćivanjem vizuelnih sadržaja koji prikazuju emocije. Takođe se želi ispitati da li je izraženost depresivnih simptoma povezana sa produženim vremenom reagovanja $u$ eksperimentalnom zadatku, kao i to da li tačnost vizuelnog pamćenja emotikona zavisi od broja elemenata u setu. Istraživanje je realizovano na uzorku od 84 ispitanika, studenata Filozofskog fakulteta u Banjoj Luci (90\% ženskog pola). PHQ-9 upitnik je korišten za procjenu depresivnih simptoma, a zadatak za ispitivanje vizuelnog pamćenja je kreiran u softverskom paketu SuperLab 4.1 for Windows. Rezultati pokazuju da postoji parcijalni doprinos umjerene depresivnosti na tačnost pamćenja emotikona sa ekspresijom tuge. Nije utvrđen parcijalni doprinos ni jedne kategorije depresivnosti na tačnost pamćenja emotikona sa ekspresijom sreće. Između izraženosti depresivnih simptoma i vremena reagovanja u eksperimentalnom zadatku je dobijena statistički značajna negativna korelacija za kategoriju „tužnih” stimulusa, dok nije dobijena statistički značajna korelacija za drugu kategoriju stimulusa. Utvrđeno je da se broj grešaka povećava sa povećanjem veličine seta. Dobijeni rezultati se mogu objasniti negativnom pristrasnošću i kognitivnim opterećenjem u procesu obrade informacije.
\end{abstract}

Ključne reči: vizuelno pamćenje, depresivnost, emotikoni, ekspresija tuge, ekspresija sreće selfa.

\footnotetext{
${ }^{1}$ dajan.budisa@student.ff.unibl.org

Citirati rad na sledeći način: Budiša, D., Halilović, A., Jovanović, Lj., Prole, N. i Borojević, S. (2021). Depresivnosti vizuelno pamćenje specifičnih stimulusa (emotikona). Godišnjak za psihologiju, 18, 89-105. https://doi.org/ 10.46630/gpsi.18.2021.06
} 


\section{Uvod}

Ovo istraživanje je usmjereno na ispitivanje povezanosti depresivnosti sa zapamćivanjem vizuelnih sadržaja koji prikazuju emocije. Depresija predstavlja promjene u raspoloženju koje može biti sniženo, tužno ili iritabilno, ali može uključivati i promjene u drugim funkcijama kao što su psihomotoričke i kognitivne, što može biti praćeno poremećajima školskog, socijalnog i porodičnog funkcionisanja (Bernaras et al., 2019). Karakteriše je stalno osjećanje tuge i potištenosti, gubitak interesa za različite aktivnosti, nemogućnost uživanja u značajnim događajima, osjećaj krivice i sniženo samopoštovanje (Vulić-Prtorić, 2004).

Depresija se može odnositi i na trenutno stanje u kom se pojedinac nalazi, a koje predstavlja normalnu reakciju na neke neprijatne ili stresne situacije i okolnosti (Novović et al., 2007). Trajanje i intenzitet tog stanja odgovara važnosti i značenju same situacije koja ga je izazvala, pri čemu osoba uspijeva sačuvati samopoštovanje i kontakte sa drugima, kao i kontrolu nad svojim promjenama raspoloženja. U istraživanju Rančić i saradnika (Rančić et al., 2019) pokazana je značajna izraženost depresivnih simptoma kod normalne, nekliničke populacije. Uzorak istraživanja su činili studenti medicine, a rezultati su pokazali da više od polovine ispitanika ima izražene depresivne simptome različite težine, što su autori objasnili izloženošću stresnim situacijama tokom studiranja. Izraženost depresivnih simptoma se može povećati i u preoperativnom periodu kod pacijenata kojima nije dijagnostikovana depresija (Vuković i Hadživuković, 2016). Zbog toga neki autori depresivnost posmatraju u terminima kontinuuma, od normalne, povremene i prolazne, do duboke depresije koja traje (Vulić-Prtorić, 2004). Bez obzira o kojoj vrsti je riječ, ono što se izdavaja kao zajednička karakteristika jeste promijenjeno emotivno stanje koje može da oblikuje naš psihički život, misli i ponašanje. Depresivno stanje praćeno sniženim raspoloženjem utiče na proces učenja i prisjećanja na način da lakše učimo i reprodukujemo ono što je u saglasnosti sa našim raspoloženjem (Bedli, 2004).

Depresija je povezana i sa abnormalnošću u prepoznavanju facijalnih ekspresija emocija (Anderson et al., 1986). Sposobnost prepoznavanja i identifikovanja facijalnih ekspresija emocija je osnova za funkcionisanje u socijalnim mrežama i interpersonalnim odnosima. To je osnova za ljudsku interakciju i ima značajan efekat na ponašanje i afektivno stanje (Bourke et al., 2010). Kada su u pitanju emocije, Ekman (1992) je opisao šest bazičnih emocija koje uključuju tugu, sreću, iznenađenje, ljutnju, gađenje i strah. Odrasli sa anksioznim poremećajima ili depresijom imaju poteškoće u prepoznavanju facijalnih ekspresija emocija i taj deficit je više izražen kod onih sa dijagnostikovanom depresijom (Demenescu et al., 2010). U kontekstu objašnjenja depresije, često se pominje negativna pristrasnost (eng. negative bias) kao centralna komponenta kognitivnih modela depresije (Cowden \& Amir, 2012). Negativna pristrasnost se ogleda u tome da osobe sa depresijom imaju tendenciju da dvosmislene informacije interpretiraju negativno. Postoji mogućnost da je samofokusirana ruminacija jedan od značajnih uzročnih mehanizama kojima se objašnjava negativna pristrasnost depresivnih osoba pri prepoznavanju 
facijalnih emocija drugih ljudi (Raes et al., 2006). U istraživanju koje se sproveo Gilbo-Šektmen sa saradnicima (Gilboa-Schechtman et al., 2002) depresija je bila povezana sa smanjenom sposobnošću prepoznavanja facijalnih ekspresija sreće i boljim prepoznavanjem facijalnih ekspresija ljutnje. Postoje i studije koje pokazuju da depresivni ispitanici prepoznaju facijalne ekspresije i pozitivnih i negativnih emocija sa većom tačnošću u poređenju sa nedepresivnim (Harkness et al., 2010). Isti rezultati su dobijeni i u istraživanju koje su sproveli Vu i saradnici (Wu et al., 2012) koji su klasičnim bihejvioralnim mjerama dodali i mjere praćenja pokreta očiju prilikom zadatka prepoznavanja. Ispitivali su razlike između ispitanika sa visoko i nisko izraženim simptomima depresije u tačnosti prepoznavanja facijalnih ekspresija i utvrdili značajno veću uspješnost kod ispitanika sa visoko izraženim simptomima depresijeu odnosu na kontrolnu grupu ispitanika bez depresivnih simptoma. Izraženost depresivnih simptoma nije uticala na tačnost prepoznavanja, te su autori svoje nalaze objasnili naglašavanjem značaja kognitivnog procesa selektivne pažnje, a ne sposobnošću dekodiranja izraza lica. Jedina razlika koja se pojavila u odnosu na stepen izraženosti depresivnih simptoma je bila dužina fiksacija oka na pojedinim dijelovima prikazanih stimulusa. Ispitanici sa visoko izraženim depresivnim simptomima su duže posmatrali lijevu polovinu prezentovanih facijalnih ekspresija (Wu et al., 2012). To se objašnjava hipotezom o dominantnoj moždanoj hemisferi prema kojoj je desna moždana hemisfera dominantna u ekspresiji i percepciji emocija (Ognjenović \& Škorc, 2005). U studijama u kojima su se pratili EEG signali tokom prepoznavanja stimulusa je utvrđena pojačana aktivnost desne hemisfere prilikom obrade emocionalnih sadržaja i lica (Hay, 1981; Le Grand et al., 2003).

Tačna obrada emocionalnih informacija je važna jer omogućava pružanje odgovarajućih afektivnih povratnih informacija i usvajanje dosljednih obrazaca ponašanja od čega zavisi kvalitet socijalnih interakcija (Esposito, 2013). Emotikoni predstavljaju novi kanal komunikacije koji se zadnjih godina koriste sve učestalije. To su zapravo idiogrami nastali kombinacijom određenih karaktera koji treba da liče na facijalnu ekspresiju različitih emocija (Chatzichristos et al., 2020; Rajhi, 2017). Takvi grafički simboli omogućavaju brzi prenos signala i olakšavaju izražavanje i razumijevanje emotivnih iskustava, te mogu biti potpuno samostalan nosilac informacije. Nedavno realizovano istraživanje prepoznavanja emotikona sa različitim emocionalnim ekspresijama je pokazalo visoku tačnost u prepoznavanju emocija sreće i tuge, dok je tačnost prepoznavanja iznenađenja, gađenja, straha i ljutnje bila nešto niža (Borojević i Stančić, 2020). Navedeno istraživanje je pružilo određena saznanja o opažanju emotikona kod nedepresivnih. O vezi depresivnosti i emotikona govori jedino istraživanje grupe autora (Van Dam et al., 2019) koji su kroz pilot studiju nastojali da provjere da li se na osnovu upotrebe emotikona tokom dužeg vremenskog perioda može utvrditi dominantno afektivno stanje osobe. Takođe su pokušali da ispitaju da li je procjena emotikona (pozitivna ili negativna) povezana sa problemima mentalnog zdravlja. Rezultati su pokazali da ne postoje razlike u procjeni valence emotikona između mladih iz ,kliničke” grupe i mladih iz kontrolne grupe, niti su pozitivni i negativni emotikoni povezani sa mentalnim problemima i rezilijentnošću (Van Dam et al., 2019). Zbog nedovoljno empirijskih 
provjera, fokus ovog istraživanja je upravo na ovoj specifičnoj vrsti savremenih instrumenata komunikacije.Oslanjajući se na nalaze studije koja je koristile tehnike neurooslikavanja (Churches et al., 2014) i pokazala da opažanje emotikona i realnih ljudskih lica aktivira iste moždane reagione, smatramo da i emotikoni mogu poslužiti kao značajno sredstvo za istraživanje emocionalnog doživljavanja i izražavanja, posebno zbog njihove sve veće upotrebe u svakodnevnoj komunikaciji.

Istraživanja depresivnosti pokazuju da ona ima različite efekte $i$ na samo ponašanje ispitanika u eksperimentalnim zadacima. Usljed psihomotorne usporenosti, gubitka energije i ineteresovanja za svakodnevne aktivnosti, obično dolazi do sporijeg vremena reagovanja (Tsourtos et al., 2002). Iverson (2006) je sprovodoći kompjuterski neuropsihološki skrining utvrdio da je kod depresivnih studenata sporije i vrijeme reagovanja i brzina obrade. Dok se vrijeme reagovanja odnosi na motoričku brzinu, brzina obrade se odnosi na „kognitivno usporavanje”. Naime, brojne studije su pokazale da depresija utiče na kognitivno funkcionisanje. Obično izaziva deficite u različitim domenima kao što su pažnja, memorija i izvršne funkcije (McIntyre et al., 2015). Ranija istraživanja su utvrdila da je oštećenje vizelne memorije jedna od značajnijih karakteristika memorijskog deficita kod depresivnih pacijenata (Griffiths et al., 2008). Vizuelna kratkoročna memorija (VKM) se definiše kao memorijski sistem koji čuva vizuelne informacije nekoliko sekundi tako da se može koristiti u službi tekućih kognitivnih zadataka (Luck, 2007). Ona je dio kratkoročne memorije, a informacije koje zadržavamo u njoj mogu biti dalje obrađene kroz radnu memoriju, mogu preći u dugotrajnu ili pak biti zaboravljene. Pamćenje određenih informacija može biti određeno raspoloženjem osobe. Ukoliko smo se sa određenim zadatkom, stavkom ili informacijom sreli u tužnom raspoloženju, veća je vjerovatnoća da će one biti izvučene kada opet budemo tužni. Depresija i favorizuje opažanje i prisjećanje sadržaja koji su u skladu sa depresivnim raspoloženjem.

U ovom istraživanju smo željeli ispitati vizuelno pamćenje specifičnih stimulusa, emotikona, koji prikazuju prijatne i neprijatne emocije, odnosno sreću i tugu. U skladu sa tim, prva hipoteza istraživanja je da se osobe sa višim skorovima na skali depresivnosti bolje prisjećaju neprijatnih emocija, odnosno da prave manje grešaka u pamćenju emotikona čija je ekspresija usmjerena na tugu. Takođe smo željeli da ispitamo da li su i na koji način povezani depresivnost i brzina reagovanja u eksperimentalnom zadatku, te smo u skladu sa ranijim istraživanjima definisali drugu hipotezu - ispitanici sa višim skorom na skali depresivnosti inaju generalno sporije vrijeme reakcije na stimuluse zbog nekih od simptoma depresivnosti - psihomotorne usporenosti i gubitka energije. Treća hipoteza istraživanja se odnosila na povezanost broja stimulusa (emotikona) i tačnost pamćenja. Luck i Vogel (Luck \& Vogel, 1997) su pokazali da mladi ljudi mogu održati tri do četiri jednostavne boje ili objekta u kratkotrajnoj memoriji, te je u skladu s tim očekivano da sa povećanjem broja emotikona raste i kognitivno opterećenje, te da će sa rastom broja stimulusa rasti i procenat grešaka u pamćenju. 


\section{Metod}

\section{Uzorak}

Podaci su prikupljeni na uzorku od 84 ispitanika. U pitanju je bio prigodan uzorak koji su činili studenti Studijskog programa psihologije i Studijskog programa pedagogije Filozofskog fakulteta Univerziteta u Banjoj Luci ( $90 \%$ ženskog pola) uzrasta od $20-25$ godina $(M=21.7, S D=1.4)$.

\section{Procedura}

Eksperimentalni dio istraživanja je realizovan na prenosivom računaru, pri čemu su ispitanici sjedili na 50 centimetara udaljenosti od njega. Na ekranu računara su izlagane serije emotikona $u$ trajanju od 10 sekundi, a zadatak ispitanika je bio da zapamte pozicije (raspored) prezentovanih stimulusa. Serije stimulusa su sadržavale emotikone sa istom ekspresijom koji su bili različite boje, pri čemu se boja nije ponavljala u jednom izlaganom setu. Nakon toga, ispitanicima je prikazan jedan emotikon (meta) a oni su trebali da odgovore na pitanje na kojoj poziciji je on prezentovan. U setu "tužnih" emotikona, meta je bila jedan od prezentovanih grafičkih simbola iste ekspresije ali određene boje. Isti princip izlaganja je primijenjen i za "sretne" emotikone. Izlagane su naizmjenično serije od dva, tri, četiri, pet, šest i sedam emotikona sa sretnim, odnosno tužnim ekspresijama. Svakom ispitaniku je izloženo ukupno 24 serijestimulusa, koje su bile odvojene pauzama u trajanju od 10 sekundi. Ispitanici su odgovarali na kojoj se poziciji nalazio emotikon-meta nakon svake serije. Pratila se brzina davanja odgovora, odnosno vrijeme proteklo od prikazivanja pitanja do pritiska odgovarajućeg tastera. Takođe se pratila tačnost u određivanju pozicije stimulusa-mete. Pozicija mete se mijenjala u svakom izlaganju. Svi stimulusi su bili prezentovani na unaprijed definisanim pozicijama u odnosu na koje se vršilo kodiranje tačnih odgovora u softverskom paketu SuperLab. Po završetku eksperimentalnog dijela, ispitanici su popunjavali upitnik PHQ-9 kojim se procjenjivao intenzitet depresivnih simptoma. Svi ispitanici su testirani individualno.

\section{Instrumenti}

Upitnik o zdravlju pacijenata (Patient Health Questionnaire, PHQ-9; Kroenke \& Spitzer, 2009) ${ }^{2}$ - korišćena je verzija upitnika adaptirana za naše govorno područje (Subotić, 2016). Upitnik je namijenjen samoprocjeni simptoma depresivnosti. Sastoji se od 9 čestica, a ispitanici izražavaju svoje slaganje sa navedenim tvrdnjama u svakoj čestici zaokružujućiodgovore na skali od $0=$ nikada do $3=$ skoro svaki dan. Skor na PHQ-9 upitniku može da bude u rasponu od 0 do 27, a u zavisnosti od skora koji ispitanika ostvari svrstava se u jednu od kategorija depresivnh simptoma (bez simptoma, minimalna depresija 1-4, blaga depresivnost 5-9, umjerena depresivnost 10-14, umjereno teška 15-19 i teška depresivnost $>20$ ). Upitnik ima svrhu samo u procjeni intenziteta depresivnih simptoma, ali ne predstavlja potvrdu dijagnoze

\footnotetext{
${ }^{2}$ Upitnik je slobodan za korištenje u istraživačke svrhe
} 
depresije. Pouzdanost interne konzistencije upitnika u prethodnim istraživanjima rađenim na domaćem uzorku je iznosila $\alpha=.85$ (Subotić et al., 2015), $\alpha=.91$ (Delić i sar., 2018), dok je u ovom istraživanju dobijena nešto niža pozdanost koja se može smatrati prihvatljivom $(\alpha=.75)$.

SuperLab for Windows - licenciran softver za kreiranje eksperimenata je korišten za zadatak vizuelnog pamćenja.

\section{Stimulusi}

Stimulusi su kreirani pomoću programa Paint u Windows softveru. Odabrani su emotikoni sa ekspresijom sreće i sa ekspresijom tuge (primjer stimulusa je dat na Grafiku 1). Emotikoni su bili u različitim bojama, pri čemu je svaka boja prikazana jednak broj puta.

\section{Grafik 1}

Primjer stimulusa u zadatku vizuelnog pamćenja
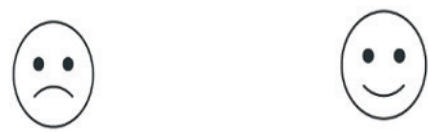

\section{Analiza podataka}

Za provjeru istraživačkih hipoteza koristili smo sljedeće statističke postupke: 1) Binarnu logističku regresiju za utvrđivanje vjerovatnoće uspješnog rješavanja zadatka vizuelne memorije na osnovu dva prediktora (depresivnost i vrsta emotikona); Emotikoni su tretirani kao binarna varijabla, gdje je „tužni” emotikon imao jednu vrijednost, a „sretni“ drugu. Isti statistički postupak je primjenjen i za zasebne analize dvije vrste emotikona kako bi se utvrdila vjerovatnoća tačnih odgovora u zadataku vizuelne memorije za pojedinačne kategorije depresivnosti. Tačnost u zadatku vizuelne memorije je operacionalizovana kao zbir tačnih prepoznavanja pozicije stimulusa-mete u svakom setu; 2) Korelacionu analizu (Pirsonov koeficijent korelacije) za utvrđivanje povezanosti između brzine reagovanja i depresivnosti; 3) Analizu varijanse za testiranje značajnosti razlika u broju tačnih odgovora $u$ zavisnosti od veličine seta. 


\section{Rezultati}

U tabeli koja sledi prikazani su deskriptivni podaci za varijablu despresivnost.

\section{Tabela 1}

Desktriptivna statistika za varijablu depresivnosti

\begin{tabular}{cccccccccc}
\hline Varijabla & $N$ & $M$ & $S D$ & Min & Max & $S k$ & $S E$ & $K u$ & $S E$ \\
\hline Depresivnost & 84 & 7.02 & 3.94 & 1.0 & 20.0 & 0.99 & 0.26 & 0.58 & 0.52 \\
\hline
\end{tabular}

Napomena. $N=$ broj ispitanika; $M=$ aritmetička sredina; $S D=$ standardna devijacija; $M i n=$ najmanja vrednost; $M a x=$ najveća vrednost; $S k=$ skjunes; $K u=$ kurtozis; $S E=$ standardna greška.

\section{Grafik 2}

Distribucija depresivnosti

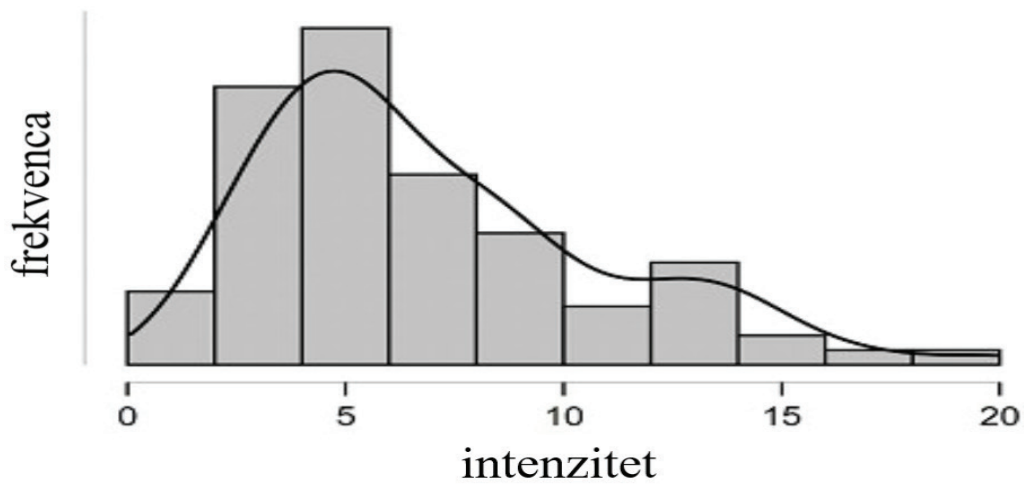

Rezultati deskriptivne statistike pokazuju prosječnu vrijednost depresivnosti na uzorku $(M=7.02, S D=3.93)$, kao i raspon skorova $(\min =1 ; \max =20)$. Na distribuciji depresivnosti se jasno vidi pozitivan skjunis $(S k=0.98)$ koji je gotovo na nivou značajne vrijednosti, odnosno distribucija je pomjerena udesno, što znači da je većina ispitanika imala nešto niže skorove na PHQ-9 skali. Korišteni upitnik depresivnosti PHQ-9 ukazuje na postojanje 6 kategorija, s tim da su na našem uzorku prisutne sve kategorije osim prve, koja se odnosi na odsustvo depresivnih simptoma. Najviše ispitanika pripada kategoriji blage depresivnosti (48.8\%), zatim minimalne depresivnosti (28.6\%), umjerene depresivnosti (17.9\%), umjereno teške depresivnosti (3.6\%), a jedan ispitanik je bio u kategoriji teške depresivnosti.

$\mathrm{Za}$ testiranje prve hipoteze, korištena je binarna logistička regresiona analiza. Naime, provjeravana je mogućnost predikcije tačnosti pamćenja prikazanih stimulusa (emotikona) na osnovu depresivnosti i vrste stimulusa. Primjenom sekvencione analize je u prvom koraku uključena depresivnost, a u drugom i vrsta emotikona. Dobijeni rezultati su prikazani u Tabeli 2. 
Dajana Budiša, Ajla Halilović, Ljiljana Jovanović, Nedeljka Prole, Svetlana Borojević

Tabela 2

Rezultati binarne logističke regresije za predviđanje uspješnosti vizuelnog pamćenja

\begin{tabular}{llccccccr}
\hline & Prediktori & $B$ & $S E$ & Wald & $p$ & $\operatorname{Exp}(B)$ & \multicolumn{2}{c}{$\begin{array}{c}\text { Intervali } \\
\text { povjerenja }\end{array}$} \\
\hline Korak 1 & Depresivnost & 0.15 & 0.06 & 5.90 & .015 & 1.16 & 1.03 & 1.31 \\
& Konstanta & 0.67 & 0.19 & 11.82 & .001 & 1.95 & & 1.32 \\
Korak 2 & Depresivnost & 0.15 & 0.06 & 5.92 & .015 & 1.16 & 1.03 & 1.58 \\
& Vrsta emotikona & 0.25 & 0.10 & 5.93 & .015 & 1.29 & 1.05 & \\
& Konstanta & 0.29 & 0.25 & 1.37 & .242 & 1.34 & & \\
\hline
\end{tabular}

Napomena. $B=$ logistički regresioni koeficijent; $S E=$ standardna greška; Wald $=$ Wald statistik; $\operatorname{Exp}(B)=$ eksponencijalni regresioni koeficijent.

Kada se u analizu uključi samo jedan prediktor rezultati pokazuju da je model statistički značajan $\left(-2 L L=2236.83, \chi^{2}(1,2016)=6.02, p<.05\right)$ i objašnjava $1 \%$ varijanse. Iz toga proizlazi da depresivnost značajno doprinosi predviđanju uspješnosti u zadatku vizuelne memorije. Procenat tačnih odgovora u odnosu na kategoriju depresivnosti je prikazan na Grafiku 3.

\section{Grafik 3}

Procenat tačnih odgovora u odnosu na kategorije depresivnosti

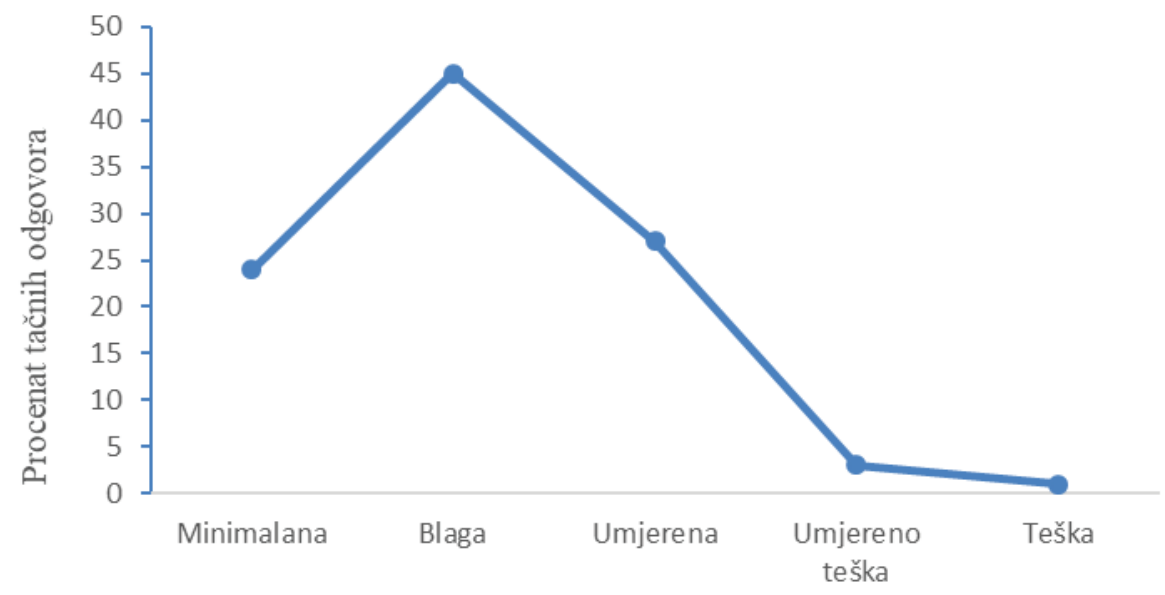

Kategorije depresivnosti

Kada se u model uključi i drugi prediktor, procenat objašnjene varijanse je nešto veći $(1.7 \%)$. Statistička značajnost modela ukazuje da postoji dodatni doprinos vrste stimulusa u objašnjenju tačnosti vizuelnog pamćenja $\left(-2 L L=2256.87, \chi^{2}(2,2016)=\right.$ $11.98, p<.01)$.

Kako se vrsta emotikona izdvojila kao značajan prediktor tačnosti vizuelnog pamćenja, pokušali smo da utvrdimo da li se vjerovatnoća tačnih odgovora za 
stimuluse koji prikazuju tužne emocije mijenja u zavisnosti od nivoa izraženosti depresivnih simptoma, te smo uradili odvojenu analizu za tu kategoriju stimulusa. Testirali smo model u koji su uključene sve kategorije depresivnosti (Tabela 3).

\section{Tabela 3}

Rezultati binarne logističke regresije za predviđanje tačnosti pamćenja „tužnih” emotikona

\begin{tabular}{lccccc}
\hline $\begin{array}{l}\text { Kategorija } \\
\text { depresivnosti }\end{array}$ & $B$ & $S E$ & Wald & $p$ & $\operatorname{Exp}(B)$ \\
\hline Minimalna & 0.27 & 0.27 & 1.07 & .301 & 1.32 \\
Blaga & 0.57 & 0.60 & 0.84 & .359 & 1.74 \\
Umjerena & 1.15 & 0.61 & 3.57 & .049 & 3.16 \\
Umjereno teška & 0.61 & 0.60 & 1.05 & .306 & 1.84 \\
Teška & 0.55 & 0.36 & 2.23 & .130 & 1.74 \\
Konstanta & 0.34 & 0.59 & 0.33 & .566 & 1.40 \\
\hline
\end{tabular}

Napomena. $B=$ logistički regresioni koeficijent; $S E=$ standardna greška; Wald = statistik; $\operatorname{Exp}(B)=$ eksponencijalni regresioni koeficijent.

Dobijeni model je statistički značajan na nivou $p<.01$ i objašnjava $2.1 \%$ varijabiliteta. Utvrđen je parcijalni doprinos kategorije umjerene depresivnosti na tačnost pamćenja ove vrste emotikona $(p<.05)$. Odds ratio iznosi 3.163, što implicira da se šansa za tačno odgovaranje u zadatku vizuelne memorije poveća 3.1 puta kada se vrijednost na ovoj prediktorskoj varijabli poveća za jednu standardnu devijaciju. Varijabla pamćenja je binarizovana varijabla, gdje se manja vrijednost odnosi na netačan odgovor, a veća vrijednost na tačan.

Kada se ista analiza sprovede samo na stimulusima koji prikazuju emociju sreće, rezultati pokazuju da je dobijeni model statistički značajan na nivou $p<.01$ i objašnjava $1.7 \%$ varijabiliteta. Međutim, ne postoje statistički značajni parcijalni doprinosi pojedinačnih kategorija depresivnosti na uspješnost u zadatku vizuelne memorije (Tabela 4.).

\section{Tabela 4}

Rezultati binarne logističke regresije za predviđanje tačnosti pamćenja „sretnih” emotikona na osnovu kategorija depresivnosti kao prediktora

\begin{tabular}{lccccc}
\hline $\begin{array}{l}\text { Kategorija } \\
\text { depresivnosti }\end{array}$ & $B$ & $S E$ & Wald & $p$ & $\operatorname{Exp}(B)$ \\
\hline Minimalna & 0.16 & 0.68 & 0.06 & .801 & 1.19 \\
Blaga & -0.17 & 0.68 & 0.07 & .798 & 0.84 \\
Umjerena & 0.15 & 0.68 & 0.05 & .820 & 1.17 \\
Umjereno teška & 0.75 & 0.69 & 1.17 & .280 & 2.12 \\
Teška & -0.14 & 0.76 & 0.04 & .851 & 0.87 \\
Konstanta & 1.10 & 0.67 & 2.72 & .099 & 3.00 \\
\hline
\end{tabular}

Napomena. $B=$ logistički regresioni koeficijent; $S E=$ standardna greška; Wald = statistik; $\operatorname{Exp}(B)=$ eksponencijalni regresioni koeficijent. 
Kako bismo provjerili drugu hipotezu sproveli smo dvije odvojene korelacione analize. Prvom analizom smo provjeravali povezanost depresivnosti i vremena reakcije za emotikone sa tužnom ekspresijom, dok smo u drugoj analizi ispitivali povezanost istih varijabli ali za drugu kategoriju stimulusa, emotikona sa ekspresijom sreće. Suprotno početnoj pretpostavci, Pirsonov koeficijent korelacije u analizi „tužnih” emotikona je negativan i statistički značajan $(r=-.24, p<.05)$ što implicira da su ispitanici sa višim skorom na skali depresivnosti imali bržu reakciju kada je u pitanju pamćenje ove vrste vizuelnih stimulusa. Koeficijent korelacije između brzine reagovanja i depresivnosti za kategoriju "sretnih" emotikona nije statistički značajan $(r=-.12, p>.05)$.

Treća hipoteza istraživanja je u potpunosti potvrđena. Na Grafiku 4 je predstavljena distribucija grešaka kroz ponavljanja koja se razlikuju po broju elemenata. Može se vidjeti da se broj grešaka značajno povećava sa povećavanjem veličine seta $(F(5,2016)=23.481, p<.001)$.

\section{Grafik 4}

Distribucija grě̌aka u odnosu na veličinu seta

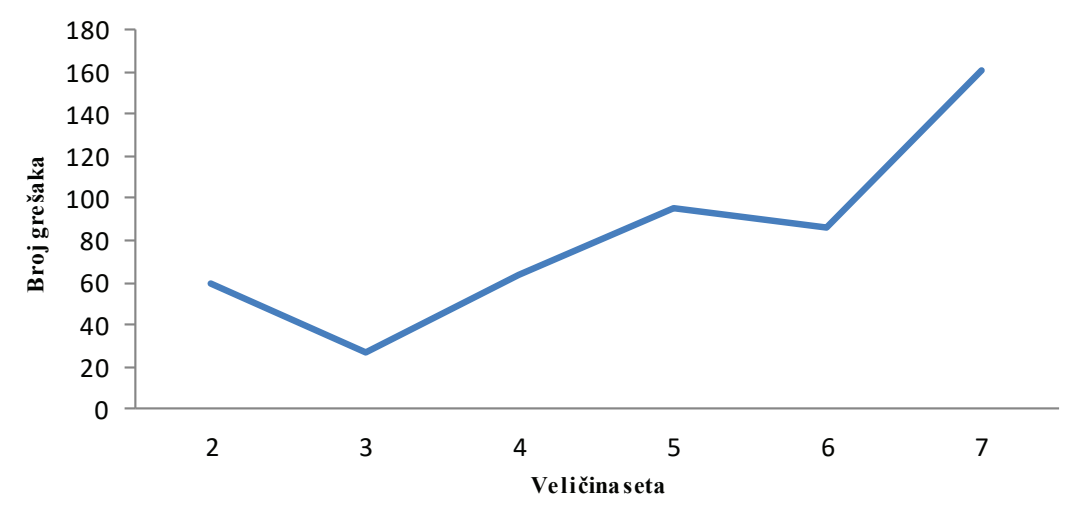

\section{Diskusija}

Iako se depresivnost primarno odnosi na afektivne smetnje i poremećaje, ona ima značajan efekat i na kognitivno funkcionisanje. Najčešće dovodi do problema u usmjeravanju i održavanju pažnje, ali i usvajanju i zadržavanju novih informacija. Ranije studije su utvrdile da je oštećenje vizelne memorije jedna od značajnijih karakteristika memorijskog deficita kod depresivnih pacijenata (Griffiths et al., 2008). S druge strane, utvrđeno je i da depresija favorizuje opažanje i prisjećanje sadržaja koji su u skladu sa depresivnim rapoloženjem (Bedli, 2004), a takođe je povezana i sa promjenama u prepoznavanju facijalnih ekspresija (Anderson et al, 2011). Neke studije pokazuju da osobe sa depresivnim smetnjama imaju poteškoće 
u tačnom prepoznavanju emocionalnih izraza (Demenescu et al., 2010), dok druge studije pokazuju čak veći stepen tačnosti kod depresivnih u odnosu na nedepresivne (Harkness et al., 2010). Ova studija je pokušala da ispita odnos između depresivnosti i pamćenja specifičnih vizuelnih stimulusa koji sadrže infomacije o emocionalnim ekspresijama sreće i tuge. Ti stimulusi su bili emotikoni, jerposljednjih godina imaju veliku ulogu u svakodnevnoj komunikaciji, posebno u sferi digitalnekomunikacije. Oni zapravo predstavljaju "alternativni kanal" prenosa informacija u odsustvu fizičkog prisustva sagovornika. Iako su emotikoni statični, neverbalni i slikovni simboli dosta jednostavne strukture, postoje nalazi koji ukazuju da mogu biti validno sredstvo $\mathrm{u}$ ispitivanju emocionalnog izražavanja i socijalnih interakcija. Opažanje emotikona izaziva aktivaciju istih moždanih regiona kao i opažanje ljudskih lica (Churches et al., 2014). Razumijevanje teksta određene emocionalne valence može biti ubrzano ukoliko je dopunjeno emotikonima, ali prezentovanje samog teksta izaziva aktivaciju različitih moždanih struktura, ali ne i fuziformnog girusa kao u slučaju prikazivanja samostalnih emotikona, a koji je značajan u prepoznavanju lica (Yuasa et al., 2011). Ovim istraživanjem smo željeli ispitati pojavu negativne pristrasnosti na specifičnoj kategoriji stimulusa, ali i odnos depresivnih simptoma i brzine reagovanja u eksperimentalnom zadatku, kao i kapacitet vizuelne memorije za spomente stimuluse. Dobijeni rezultati su djelimično potvrdili početne pretpostavke. Utvrđeno je da su i depresivnost i vrsta emotikona statistički značajni prediktori uspješnosti u zadatku vizuelne memorije. Rezultati su pokazali da je najmanja tačnost prisutna kod umjereno teške i teške depresivnosti. Kako se vrsta emotikona izdvojila kao značajan prediktor, u cilju provjere početne pretpostavke urađene su odvojene analize za tužne i za sretne emotikone, sa kategorijama depresivnosti kao prediktorima. U analizi parcijalnih doprinosa pojedinih kategorija depresivnosti utvrđeno je da se na osnovu umjerene depresivnosti može statistički značajno predvidjeti tačnost pamćenja "tužnih" emotikona, dok kod pamćenja "sretnih" emotikona nije izdvojen ni jedan parcijalni doprinos. Kod ispitanika koji imaju umjereno izražene depresivne simptome je povećana vjerovatnoća tačnog zapamćivanja pozicije stimulusa sa ekspresijom tuge. Taj nalaz je u skladu sa ranijim studijamakoji govore o pristrasnosti depresivnih osoba ka neprijatnim i negativnim stimulusima (Beck, 1967), te boljem prisjećanju neprijatnih emocija i neprijatnih emocionalnih iskustava (Gilboa-Schechtman et al., 2002; Urban et al., 2018) što se objašnjava fenomenom negativne pristrasnosti u okviru kognitivnih modela depresije.Takav kognitivni mehanizam se zasniva na selektivno usmjerenoj pažnji prema negativnim emocionalnim znakovima, što poboljšava njihovo prepoznavanje i memorisanje (Leppanen, 2006). Moguće objašnjenje dobijenih rezultata se ogleda $i$ u tome da negativna šema sebe i drugih, povezana sa depresivnošću, facilitira obradu emocionalnih informacija $i$ dovodi do generalizovane senzitiziranosti na izraze lica koji predstavljaju negativne emocije (Wu et al., 2012).Potvrđena je hipoteza o povezanosti pamćenja sa brojem izlaganih stimulusa. Dobijeni rezultati ukazuju na to da se sa povećanjem broja emotikona u setu, pravi i veći broj grešaka, što je u skladu sa prethodnim nalazima o kognitivnom opterećenju, odnosno kapacitetu vizuelne kratkotrajne memorije (Luck \& Vogel, 1997). Ipak, uprkos psihomotoričkoj 
agitaciji, odnosno naglašenoj usporenosti mišljenja i pokreta, jednom od simptoma depresije (DSM-5; American Psychiatric Association, 2013) pretpostavka o dužem vremenu reakcije kod ispitanika sa višim nivoom depresivnosti, nije potvrđena. Štaviše, dobijena korelacija je negativna i statistički značajna, što ukazuje na to da su osobe sa više depresivnih simptoma imale kraće vrijeme reakcije, odnosno da su se brže prisjećali pozicije vizuelnih simulusa, tj. emotikona. Takvi rezultati su dobijeni samo za kategoriju ,tužnih” emotikona, dok kod ,sretnih” nije dobijena statistički značajna korelacija. Iako su takvi rezultati neočekivani, oni se mogu objasniti upravo kognitivnim mehanizmima fokusiranosti na negativne signale za prepoznavanje. Usljed negativne pristrasnosti i veće usmjerenosti na emotikone sa negativnim ekspresijama, ispitanici brže uče raspored tih stimulus-meta, pa je samim tim i skraćeno vrijeme reagovanja u davanju odgovora. U nekoliko studija je dobijen sličan efekat smanjenog vremena reagovanja kod depresivnih u odnosu na nedepresivne ispitanike (Ahorsu et al., 2020; Bieliauskas \& Lamberty, 1995). Opšti zaključak koji iz njih proizlazi jeste da postoji distinkcija između motorne i kognitivne brzine. Prva je vezana za brzinu reagovanja u zadacima, a druga za brzinu obrade informacija. Ispitanici sa depresivnim simptomima koji nemaju kognitivno oštećenje, mogu sa jednakom efikasnošću prolaziti kroz procesuiranje informacija kao i nedepresivni, pri čemu zbog pojačane usmjerenosti na negativne stimuluse može doći do značajnog smanjenja brzine motornog reagovanja. Dobijeni nalazi se mogu objasniti i rezultatima studije koja je koristila tehniku za vizualizaciju moždane aktivnosti koja je kod ispitanika sa izraženim depresivnim simptomima pokazala brzu i pojačanu aktivaciju amigdale prilikom prikazivanja negativnih facijalnih ekspresija (Fales et al., 2008). Aktivacija tih subkrotikalnih struktura predstavlja „kraći”, a ujedno i brži put obrade emocionalne informacije.

\section{Zaključak}

Glavni cilj istraživanja je bio ispitivanje relacija između izraženosti depresivnih simptoma, vizuelne memorije i prepoznavanja emocija predstavljenih posebnim grafičkim simbolima (emotikonima). Dobijeni rezultati pokazuju da su depresivnost i vrsta emotikona značajni prediktori uspješnosti u zadatku vizuelne memorije. Kada je u pitanju tačnost prepoznavanja emotikona sa ekspresijom tuge, utvrđen je parcijalni doprinos umjerene depresivnosti. Takođe je utvrđeno da je vrijeme reagovanja $u$ zadatku u negativnoj korelaciji sa simptomima depresivnosti, ali samo za jednu kategoriju emotikona. Tačnost vizuelnog pamćenja zavisi od broja elemenata seta. Dobijeni rezultati se objašnjavaju negativnom pristrasnošću, odnosno kognitivnim mehanizmima. Teorijski značaj ovog istraživanja se ogleda u sticanju dodatnih saznanja o efektima depresivnih stanja na vizuelnu memoriju, ali i emocionalno izražavanje i doživljavanje. Dobijeni rezultati imaju značaj i za razumijevanje deficita u socijalnim interakcijama kod depresivnijih ispitanika. Takođe se proširuju znanja o negativnoj pristrasnosti ka pamćenju neprijatnih sadržaja kod depresivnijih osoba, ne samo kada su u pitanju lična iskustva, već i vizuelni sadržaji, u ovom slučaju 
facijalne eksperesije emocija. Korištenjem emotikona kao neverbalnih simbola $u$ oblasti socijalnih i emocionalnih interakcija, otvaraju se novi putevi istraživanja ovih aspekata ljudskog funkcionisanja. Uvođenjem emotikona kao novog sredstva komunikacije dobijaju se nova saznanja na osnovu kojih možemo raditi na podsticanju socijalnih vještina i to prvenstveno onih koji se odnose na neverbalnu komunikaciju i prepoznavanje emocionalnih ekspresija kod depresivnih ispitanika.Ovaj rad ima i nekoliko nedostataka koji se prije svega odnose na uzorak. Naredno istraživanje bi trebalo realizovati na većem broju ispitanika, ujednačenom po polu i sa nasumično odabranim ispitanicima. Pored odabranih emocija, sreće i tuge, može se ispitati vizuelno pamćenje i za druge kategorije primarnih emocija. Takođe bi trebalo ispitati pristrasnosti ka pamćenju neprijatnih emocija kod ispitanika sa dijagnostikovanom depresijom i uporediti rezultate sa nekliničkom populacijom, kako bi se utvrdile eventualne razlike.

\section{Literatura}

Ahorsu, D., Chung, K., Wong, H., Yiu, M., Mok, Y., Lei, K., \& Tsang, H. (2020). Effect of major depressive disorder on the sequential organization of information processing stages: an event-related potential study. Brain Sciences, 10(12), Article 935. https:// doi.org/10.3390/brainsci10120935

American Psychiatric Association, DSM-5 Task Force. (2013). Diagnostic and statistical manual of mental disorders: DSM-5 ${ }^{\text {тм }}$ (5th ed.). American Psychiatric Publishing, Inc.. https://doi.org/10.1176/appi.books.9780890425596

Anderson, I. M., Shippen, C., Juhasz, G., Chase, D., Thomas, E., Downey, D., Toth, Z. G., \& Balney, P. H. (1986). Affect and memory: A review. Psychological Bulletin, 99(2), 229-246.

Beck, A. T. (1967). Depression: Clinical, experimental, and theoretical aspects. Hoeber.

Bedli, A. (2004). Ljudsko pamćenje: Teorija i praksa. Zavod za udžbenike i nastavna sredstva.

Bernaras, E., Jaureguizar, J., \& Garaigordobil, M. (2019). Child and adolescent depression: A review of theories, evaluation instruments, prevention programs and treatments. Frontiers in Psychology, 10, Article 543. https://doi.org/10.3389/fpsyg.2019.00543

Bieliauskas, L., \& Lamberty, G. (1995). Simple reaction time and depression in the elderly. Aging, Neuropsychology and Cognition, 2(2), 128-131. https://doi. org/10.1080/13825589508256592

Borojević, S. i Stančić, S. (2020, 6. novembar). Uspješnost prepoznavanja osnovnih emocija iu generičkog seta emotiokona: Eksplorativna studija[Izlaganje rada].21. Banjalučki novembarski susreti. Knjiga rezimea, Banja Luka, Filozofski fakultet.

Bourke, C., Douglas, K., \& Porter, R. (2010). Processing of facial emotion expression in major depression: a review. Australian \& New Zealand Journal of Psychiatry, 44(8), 681-696. https://doi.org/10.3109\%2F00048674.2010.496359 
Chatzichristos, C., Morante, M., Andreadis, N., Kofidis, E., Kopsinis, Y., \& Theodoridis, S. (2020). Emojis influence autobiographical memory retrieval from reading words: An fMRI-based study. PLoS ONE, 15(7), Article e0234104. https://doi.org/10.1371/ journal.pone.0234104

Churches, O., Nicholls, M., Thiessen, M., Kohler, M., \& Keage, H. (2014). Emoticons in mind: an event-related potential study. Social Neuroscience, 9(2), 196-202. https:// doi.org/10.1080/17470919.2013.873737

Cowden, A. H., \& Amir, N. (2012). Negative interpretation bias in individuals with depressive symptoms. Cognitive Therapy and Research, 36(5), 502-511. https://doi. org/10.1007/s10608-011-9397-4

Delić, A., Subotić, S., \& Berberović, DŽ. (2018). Psihometrijska evaluacija skale općeg zadovoljstva životom (SOZŽ). DHS-društvene i humanističke studije, 2(5), 341-364.

Demenescu, L. R., Kortekaas, R., den Boer, J. A., \& Aleman, A. (2010). Impaired attribution of emotion to facial expressions in anxiety and major depression. PLoS ONE, 5(12), Article e15058. https://doi.org/10.1371/journal.pone.0015058

Ekman, P. (1992). Facial expressions of emotion: New findings, new questions. Psychological Science, 3(1), 34-38. https://doi.org/10.1111/j.1467-9280.1992.tb00253.x

Esposito A. (2013). The situated multimodal facets of human communication. In M. Rojc, N. Campbell (Eds.). Coverbal synchrony in human-machine interaction (pp. 173202). Taylor \& Francis. https://doi.org/10.1201/b15477

Fales, C., Barch, M., Rundle, M., Mintun, M., Snyder, A., \& Cohen, J. (2008). Altered emotional interference processing in affective and cognitive control brain circuity in major depression. Biological Psychiatry, 63(4), 377-384. https://doi.org/10.1016/j. biopsych.2007.06.012

Gilboa-Schechtman, E., Erhard-Weiss, D., \& Jeczemien, P. (2002). Interpersonal deficits meet cognitive biases: memory for facial expressions in depressed and anxious men and women. Psychiatry Research, 113(3), 279-293. https://doi.org/10.1016/S01651781(02)00266-4

Griffiths, S., Scott, H., Glover, S., Bienemann, A., Ghorbel, M., Uney, J., Brown, M., Warburton, C., \& Bashir, Z. (2008). Expression of long-term depression underlies visual recognition memory. Neuron, 58(2), 186-194. https://doi.org/10.1016/j. neuron.2008.02.022

Harkness, K.L., Jacobson, J.A., Duong, D., \& Sabbagh, M.L. (2010). Mental state decoding in past major depression: effect of sad versus happy mood induction. Cognition and Emotion, 24(3), 497-513. https://doi.org/10.1080/02699930902750249

Hay, D. C. (1981). Asymmetries in face processing: evidence for a right hemisphere perceptual advantage. Quarterly Journal of Experimental Psychology Section, 33(3), 267-274.https://doi.org/10.1080/14640748108400792

Iverson, G.L. (2006). Sensitivity of computerized neuropsychological screening in depressed university students. The Clinical Neuropsychologist, 20(4), 695-701. https://doi:10.1080/138540491005857.

Kroenke, K., \& Spitzer, R. L. (2002). The PHQ-9: A new depression diagnostic and severity measure. Psychiatric Annals, 32(9), 509-515. https://doi.org/10.3928/00485713-20020901-06 
Le Grand, R., Mondloch, C. J., Maurer, D., \& Brent, H. P. (2003). Expert face processing requires visual input to the right hemisphere during infancy. Nature Neuroscience, 6(10), 1108-1112. https://doi.org/10.1038/nn1121

Leppanen, J.M. (2006). Emotional information processing in mood disorders: a review of behavioral and neuroimaging findings. Current Opinion in Psychiatry, 19(1), 34-39. https://10.1097/01.yco.0000191500.46411.00

Luck, S. J. (2007). Visual short-term memory. Scholarpedia, 2(6), Article 3328. http:// dx.doi.org/10.4249/scholarpedia.3328

Luck, S. J., \& Vogel, E. K. (1997). The capacity of visual working memory for features and conjunctions. Nature,390, 279 - 281.https://doi.org/10.1038/36846

McIntyre, R.S., Xiao, H.X., Syeda, K. et al. (2015). The prevalence, measurement, and treatement of the cognitive dimension, domain in mayor depressive disorder. CNSDrugs, 29, 577- 589. https://doi:10.1007/s40263-015-0263.

Novović, Z., Biro, M., \& Nedimović, T. (2007). Stanje depresivnosti: sindrom ili raspoloženje? Psihologija, 40(3), 447-461. https://doi.org/10.2298/PSI0703447N

Ognjenović, P., \& Škorc, B. (2005). Naše namere i osećanja. Gutenbergova galaksija.

Raes, F., Hermans, D., \& Williams, J. M. G. (2006). Negative Bias in the Perception of Others' Facial Emotional Expressions in Major Depression: The Role of Depressive Rumination. Journal of Nervous and Mental Disease, 194(10), 796-799. https://doi. org/10.1097/01.nmd.0000240187.80270.bb

Rajhi, M. (2017). Emotional recognition using facial expression by emoji in real time, International Journal of Innovative Research in Computer and Communication Engineering, 5.

Rančić, N., Kocić, B., Stević, S., Ilić, M., Stojanović, M., \& Stojanović, M. (2019). Prevalence of depressive symptoms in medical students. Acta Medica Medianae, 58(4), 18-25. https://doi.org/10.5633/amm.2019.0403

Subotić, S. (2016). Priručnik za PHQ-9 upitnik depresivnosti za psihologe u školi [radni dokument br. 03-2016]. NVO „Persona“, Banjaluka, BiH. Preuzeto sa http:// personapsiho.com/wp-content/uploads/2016/06/phq-9-skl.pdf

Subotić, S., Knežević, I., Dimitrijević, S., Miholjčić, D., Šmit, S., Karać, M., \& Mijatović, J. (2015). The factor structure of the patient health questionnaire (PHQ-9) in a nonclinical sample. In S. Subotić (Ed.), STED 2015 Conference Proceedings-Psychology Section, (pp. 20-28). University for business engineering and management. DOI: 10.7251/STED0415020S

Tsourtos, G., Thompson, J.C., \& Stough, C. (2002). Evidence of an early information processing speed deficit in unipolar major depression. Psychological Medicine, 32(2), 259-265. https://doi:10.1017/s00332991701005001

Urban, E. J., Charles, S. T., Levine, L. J., \& Almeida, D. M. (2018). Depression history and memory bias for specific daily emotions. PLoS ONE, 13(9), Article e0203574. https://doi.org/10.1371/journal.pone.0203574

Van Dam, L., Rietstra, S., Van der Drift, E., Stams, G., Van der Mei, R., Mahfoud, M., Popma, A., Schlossberg, E., Pentland, A., \& Reid, T. (2019). Can an emoji a day keep the doctor away? An explorative mixed-methods feasibility study to develop a selfhelp app for youth with mental health problems. Frontiers in Psychiatry, 10, Article 593. https://doi:org/10.3389/fpsyt.2019.00593. 
Vuković, Ž. i Hadživuković, N. (2016). Psihičke reakcije bolesnika u perioperativnom periodu. Sestrinski žurnal, 3(1), 42-47. https://doi.org/10.7251/SEZ0116042V

Vulić-Prtorić, A. (2004). Depresivnost u djece $i$ adoslecenata. Naklada slap.

Wu, L.D., Pu, J., Allen, J., \& Pauli, P. (2012). Recognition of facial expressions in individuals with elevated levels of depressive symptoms: an eye-movement study. Depression Research and Treatment, 2012, Article 249030. https://doi.org/10.1155/2012/249030

Yuasa, M., Saito, K., \& Mukawa, N. (2011). Brain activity when reading sentences and emoticons: an fMRI study of verbal and nonverbal communication. Electronics and Communications in Japan, 94(5), 1797-1803. https://doi.org/10.1002/ecj.10311

\title{
Dajana Budiša ${ }^{3}$
}

Ajla Halilović

Ljiljana Jovanović

Nedeljka Prole

Department of Psychology

Faculty of Philosophy

University of Banja Luka

Republic of Srpska, Bosnia and Herzegovina

\section{Svetlana Borojević}

The Laboratory of Experimental Psychology - LEP-BL

University of Banja Luka

Republic of Srpska, Bosnia and Herzegovina

\section{EXPRESSION AND VISUAL MEMORY OF SPECIFIC STIMULI (EMOTICONS)}

\begin{abstract}
Depression is a state of reduced psychophysical activity that is accompanied by various changes in cognitive, emotional and social functioning. Previous studies have found that depression leads to changes in the recognition of the emotions of others, makes it difficult to direct attention and significantly impairs visual memory. The main goal of this research is to examine the relations between depressive symptoms and visual memory of specific stimuli that show emotions. We also want to examine whether the intensity of depressive symptoms is related to longer reaction time in the experimental task, as well as whether the accuracy of the emoticon's visual memory depends on the set size. The research was conducted on a sample of 84 participants, students of Faculty of Philosophy in Banja Luka (90\% female). The PHQ-9 questionnaire was

\footnotetext{
${ }^{3}$ dajan.budisa@student.ff.unibl.org

Please cite as: Budiša, D., Halilović, A., Jovanović, Lj., Prole, N., \& Borojević, S. (2021). Depresivnosti vizuelno pamćenje specifičnih stimulusa (emotikona) [Expression and visual memory of specific stimuli (emoticons)]. Godišnjak za psihologiju, 18, 89-105. https://doi.org/10.46630/gpsi.18.2021.06
} 
used to assess depressive symptoms. Visual memory task was created in SuperLab 4.1. for Windows. The results show that there is a partial contribution of moderate depression to the accuracy of emoticon memory with sadness expression. No partial contribution of any category of depression to the memory accuracy of emoticons with the expression of happiness has been determined. A statistically significant negative correlation for the category of "sad" stimuli was obtained between the expression of depressive symptoms and the response time in the experimental task, while no statistically significant correlation was obtained for the second category of stimuli. It was also found that the number of errors increases with the set size. These results can be explained by negative bias and cognitive load in information processing.

Key words: visual memory, depression, emoticons, expression of happiness, expression of sadness

Primljeno: 18.04.2021.

Primljena korekcija: 27.07.2021.

Prihvaćeno za objavljivanje: 05.08.2021. 